\title{
Silencing of $c y p$-33C9 Gene Affects the Reproduction and Pathogenicity of the Pine Wood Nematode, Bursaphelenchus xylophilus
}

\author{
Xiuwen Qiu ${ }^{1,2,3, \dagger}{ }^{+}$Lili Yang ${ }^{4,+}$, Jianren $\mathrm{Ye}^{5}$, Wei Wang ${ }^{1}$, Tiantian Zhao ${ }^{1}$, Hao Hu ${ }^{1}$ and \\ Guixiang Zhou 1,2,* \\ 1 Poyang Lake Eco-economy Research Center, Jiujiang University, Jiujiang 332005, Jiangxi, China; \\ qiuxiuwen3@163.com (X.Q.); wangwei34561@163.com (W.W.); ztt18728190030@163.com (T.Z.); \\ hh502192456@163.com (H.H.) \\ 2 College of Bioscience and Bioengineering, Jiangxi Agricultural University, Nanchang 330045, Jiangxi, China \\ 3 Office of Mountain-River-Lake Development Committee of Jiangxi Province, \\ Nanchang 330046, Jiangxi, China \\ 4 College of Environment, Zhejiang University of Technology, Hangzhou 310014, Zhejiang, China; \\ Lili406421@163.com \\ 5 College of Forestry, Nanjing Forestry University, Nanjing 210037, Jiangsu, China; jryenjlydx@163.com \\ * Correspondence: gxzhou@issas.ac.cn \\ + These authors contributed equally to this work.
}

Received: 22 July 2019; Accepted: 10 September 2019; Published: 12 September 2019

\begin{abstract}
Cytochrome P450 genes are very important for plant-parasitic nematodes to reproduce and to metabolize xenobiotic compounds generated by their host plants. The pine wood nematode (PWN), Bursaphelenchus xylophilus, causes very high annual economic losses by killing large numbers of pine trees across Asia and into Europe. In this study, we used RNA interference (RNAi) to analyze the function of the cyp-33C9 gene of PWN. Our results showed that expression of the cyp-33C9 gene was suppressed successfully after soaking nematodes for $24 \mathrm{~h}$ in cyp-33C9 double-stranded RNA (dsRNA). The silencing of the cyp-33C9 gene significantly decreased the feeding, reproduction, oviposition and egg hatch of B. xylophilus. Meanwhile, the migration speed of B. xylophilus in Pinus thunbergii was reduced in the early stages when the cyp-33C9 gene was silenced in the nematodes. Moreover, knockdown of the cyp-33C9 gene in B. xylophilus caused a decrease in pathogenicity to pine trees. These results suggest that the cyp-33C9 gene plays an important role in the reproduction and pathogenicity of $B$. xylophilus. This discovery identified several functions of the cyp-33C9 gene in B. xylophilus and provided useful information for understanding the molecular mechanism behind pine wilt disease caused by PWN.
\end{abstract}

Keywords: cytochrome P450s; gene silencing; RNA interference; pine wilt disease; Bursaphelenchus xylophilus

\section{Introduction}

Pine wilt disease (PWD) is one of the most serious diseases of forest trees, affecting conifers around the world [1]. As the causal agent of PWD, the pine wood nematode (PWN), Bursaphelenchus xylophilus (Steinr and Buhrer) Nickle, is a migratory plant endoparasite [2]. B. xylophilus is considered to be native to North America, where it causes little damage to the native pine species which are resistant to the nematode [3]. However, once introduced into a new area where no natural resistance is present in the conifers, B. xylophilus has caused the death of millions of pine trees, resulting in huge economic losses [4]. At the start of the 20th century, the PWN was introduced into Japan, from where it has 
subsequently spread to other countries in Asia, such as China and Korea [5-7]. B. xylophilus was first detected in Europe in 1999 and has now been found in Portugal and Spain [8,9].

As important components of a monooxygenase system, cytochrome P450s are widely distributed in virtually all living organisms, such as mammals, plants, microorganisms and invertebrates $[10,11]$. Cytochrome P450s catalyze not only the oxidative metabolism of xenobiotic compounds, such as pesticides, drugs, mutagens and plant toxins [12], but also the synthesis and degradation of endobiotic compounds, such as steroid hormones, amino acids and fatty acids [13-15]. In addition, cytochrome P450s have been associated with other functions, including cell growth, infection, reproduction and other processes [16]. For example, cytochrome P450s are vital for the correct execution of meiosis, eggshell development and anterior-posterior polarization of the embryo in Caenorhabditis elegans [17]. Ziniel et al. demonstrated that CYP3050A1 was essential for parasite survival and egg development in the blood fluke Schistosoma mansoni [18].

The genome of B. xylophilus was sequenced in 2011 and 76 cytochrome P450 genes were detected [19]. Pine trees produce a complex mixture of nematicidal and nematistatic compounds (such as terpenoids and cyclic aromatic compounds) in response to invasion by PWNs [20,21]. The cytochrome P450s of B. xylophilus are probably involved in the catabolism of these pine tree defense chemicals [19]. The detoxification of xenobiotics by the nematode can be divided into three phases: (I) the addition of functional groups to molecules, making them more suitable substrates for the next stage; (II) the execution of detoxification reactions; (III) the release of the metabolites [22]. Cytochrome P450s play the most important role in phase I [23]. With the development of molecular research technologies in recent decades, more and more functions of cytochrome P450 genes have been revealed [24]. However, the roles of cytochrome P450 genes in the pathogenic process of B. xylophilus are currently unknown.

RNA interference (RNAi) is a powerful tool for investigating the biological functions of genes, as it causes the degradation of specific mRNA sequence by using homologous double-stranded RNA (dsRNA) to silence gene function at the post-transcriptional level [25-27]. Since it was first described in the free-living nematode C. elegans in 1998, the RNAi technique has been widely used to study gene functions in plant-parasitic nematodes, such as cyst nematodes (e.g., Globodera spp.), root-knot nematodes (e.g., Meloidogyne spp.) and migratory burrowing nematodes (e.g., Radopholus similis) [28-30]. In B. xylophilus, several essential genes, such as cellulase, arginine kinase, pectinase and heat shock protein 70 genes, have been silenced using dsRNA [31-34]. As a member of the cytochrome P450 gene family, the cyp-33C9 gene has been reported in Caenorhabditis briggsae, Caenorhabditis remanei, Caenorhabditis brenneri and B. xylophilus according to the NCBI database (https://blast.ncbi.nlm.nih.gov/B last.cgi). Up to now, the roles of the cyp-33C9 gene in these nematodes have not been well characterized.

Our previous study demonstrated that the expression of the cyp-33C9 gene in the PWN was up-regulated 6.2-fold after B. xylophilus invaded pine trees, which indicated that the cyp-33C9 gene plays an important role in the pathogenicity of the PWN [24]. Therefore, the aim of the present study was to examine the effects of silencing the cyp-33C9 gene on the morphology, development, reproduction and pathogenicity of B. xylophilus. The results of this study will not only reveal the functions of cyp-33C9 gene in B. xylophilus, but also provide useful information for elucidating the molecular mechanism of pathogenicity in the PWN.

\section{Results}

\subsection{Effects of RNA Interference (RNAi) on Feeding and Reproduction of Bursaphelenchus xylophilus}

The experiments to study the effects of RNAi on feeding and reproduction of B. xylophilus were performed on Botrytis cinerea cultures on potato dextrose agar (PDA) plates. The green fluorescent protein $(g f p)$ gene dsRNA treatment was used to evaluate the influence of non-endogenous dsRNA on feeding and reproduction of B. xylophilus. The nematodes soaked in cyp-33C9 dsRNA solution showed significantly reduced population size compared with that of nematodes soaked in $\mathrm{ddH}_{2} \mathrm{O}$ (control, CK) or $g f p$ dsRNA solution (Figure 1A). After five days incubation post-treatment on B. cinerea plates 
at $25{ }^{\circ} \mathrm{C}$, the number of B. xylophilus second-stage juveniles (J2s) per plate after inoculation with J2s treated with cyp-33C9 dsRNA, $\mathrm{ddH}_{2} \mathrm{O}$ (CK) or $g f p$ dsRNA solution were 97,970 and 890 , respectively (Figure 1B). These results suggested that feeding and reproduction of B. xylophilus were significantly suppressed by cyp-33C9 dsRNA interference.

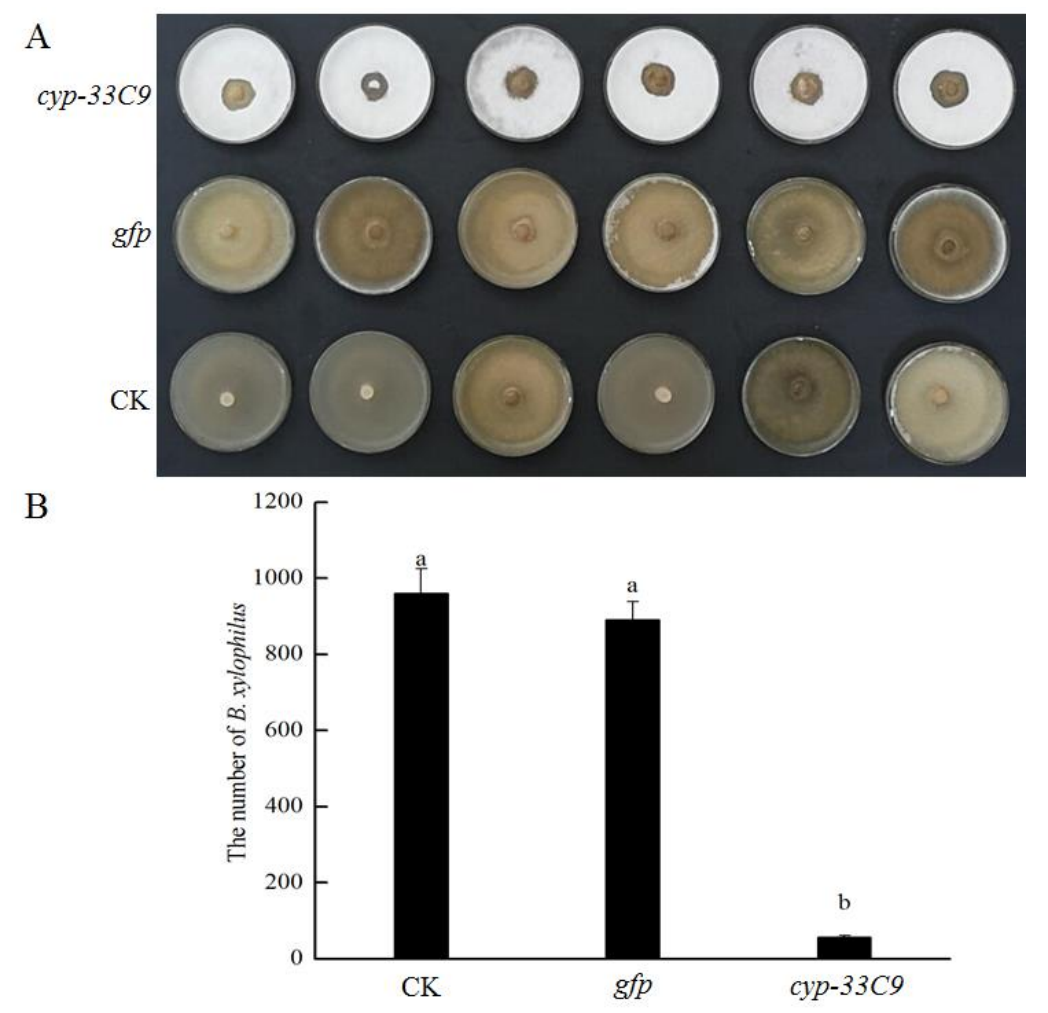

Figure 1. Effects of RNA interference (RNAi) on feeding and reproduction of Bursaphelenchus xylophilus. Botrytis cinerea cultures on potato dextrose agar (PDA) plates $5 \mathrm{~d}$ after inoculation with $200 \mathrm{~s}$-stage juveniles (J2s) soaked in $\mathrm{ddH}_{2} \mathrm{O}(\mathrm{CK})$ or dsRNA ( $g f p$ or cyp-33C9) (A); the numbers of B. xylophilus washed from PDA plates of $B$. cinerea inoculated with B. xylophilus $\mathrm{J} 2 \mathrm{~s}$ treated with $\mathrm{ddH}_{2} \mathrm{O}(\mathrm{CK})$ or dsRNA ( $g f p$ or cyp-33C9). The error bars indicate standard deviations, and treatments with different letters indicate significant differences $(p<0.05)(\mathbf{B})$.

\subsection{Effects of RNA Interference (RNAi) on Oviposition of Bursaphelenchus xylophilus}

To further assess the influence of the cyp-33C9 gene on the fecundity of B. xylophilus, the number of eggs laid per female nematode was determined. The results showed that the number of eggs laid per female nematode soaked in $\mathrm{ddH}_{2} \mathrm{O}$ and $g f p$ dsRNA solution were 23 and 22, respectively (Figure 2). However, the number of eggs laid per female nematode soaked in cyp-33C9 dsRNA solution was only 10 , which was much fewer than that from nematodes treated with $\mathrm{ddH}_{2} \mathrm{O}$ or $g f p$ dsRNA solution. These results indicated that the gene silencing of cyp-33C9 by dsRNA interference has a significant inhibitory effect on oviposition of B. xylophilus. 


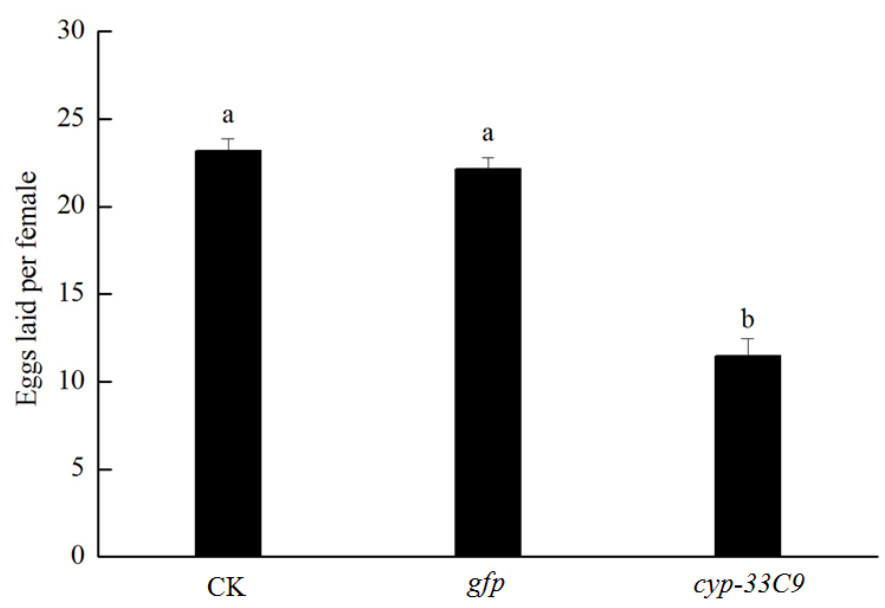

Figure 2. The oviposition of Bursaphelenchus xylophilus after RNA interference of cyp-33C9. The bars indicate standard deviation, and different letters indicate significant differences $(p<0.05)$ among treatments.

\subsection{Effects of RNAi on Hatch of Bursaphelenchus xylophilus}

The effects of RNAi silencing of cyp-33C9 on percentage hatch of B. xylophilus were similar to those on oviposition. The percentage hatch of B. xylophilus with cyp-33C9 dsRNA treatment was $52 \%$, which was lower than that with $\mathrm{ddH}_{2} \mathrm{O}$ or $g f p$ dsRNA treatments (Figure 3). No significant differences were observed between $\mathrm{ddH}_{2} \mathrm{O}$ and $g f p$ dsRNA treatments, indicating that the non-endogenous dsRNA had no obvious negative effect toward the nematodes.

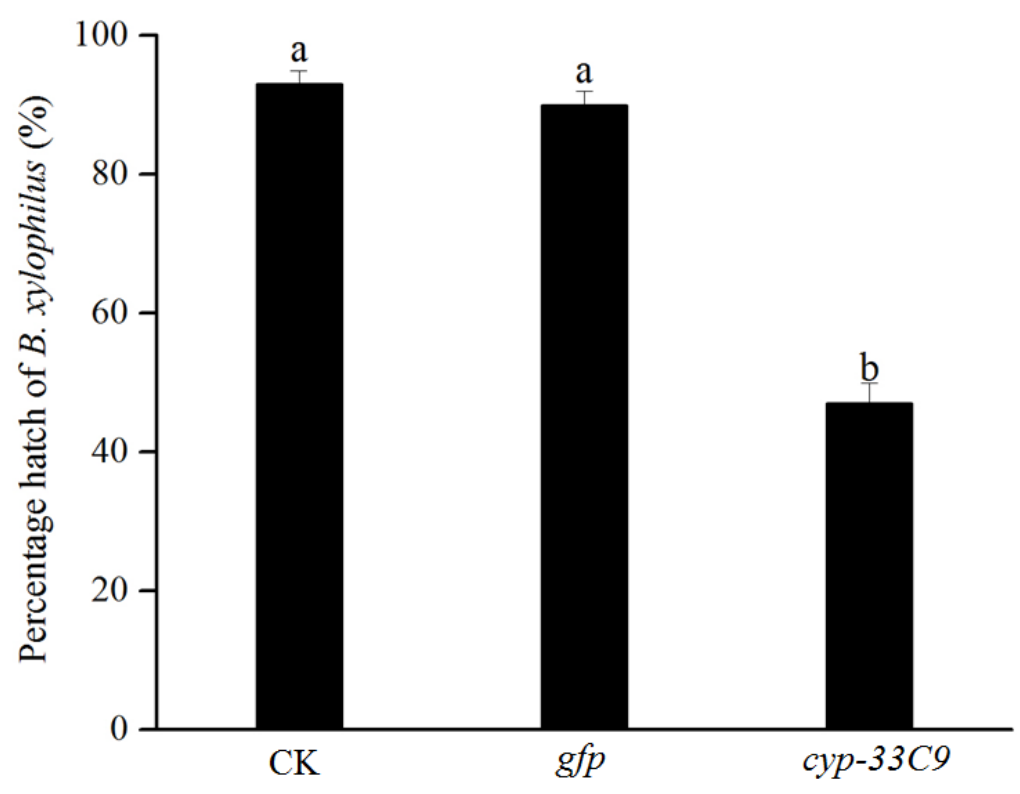

Figure 3. The percentage hatch of Bursaphelenchus xylophilus after RNA interference of cyp-33C9. The bars indicate the standard deviation, and different letters indicate significant differences $(p<0.05)$, according to Tukey's test, among the treatments.

\subsection{Effects of RNA Interference (RNAi) on Individual Body Length of Bursaphelenchus xylophilus}

After being soaked in cyp-33C9 dsRNA solution, the individual body length of both the male and female J2s was slightly but not significantly shorter $(p>0.05)$ than that following soaking in $\mathrm{ddH}_{2} \mathrm{O}$ or $g f p$ dsRNA solution (Figure 4). The body length of $B$. xylophilus following $\mathrm{ddH}_{2} \mathrm{O}$ treatment was similar to that following $g f p$ dsRNA treatment. No significant differences in body lengths between 
the three different treatments were observed, suggesting that cyp-33C9 dsRNA interference had no significant effect on the individual body length of B. xylophilus.

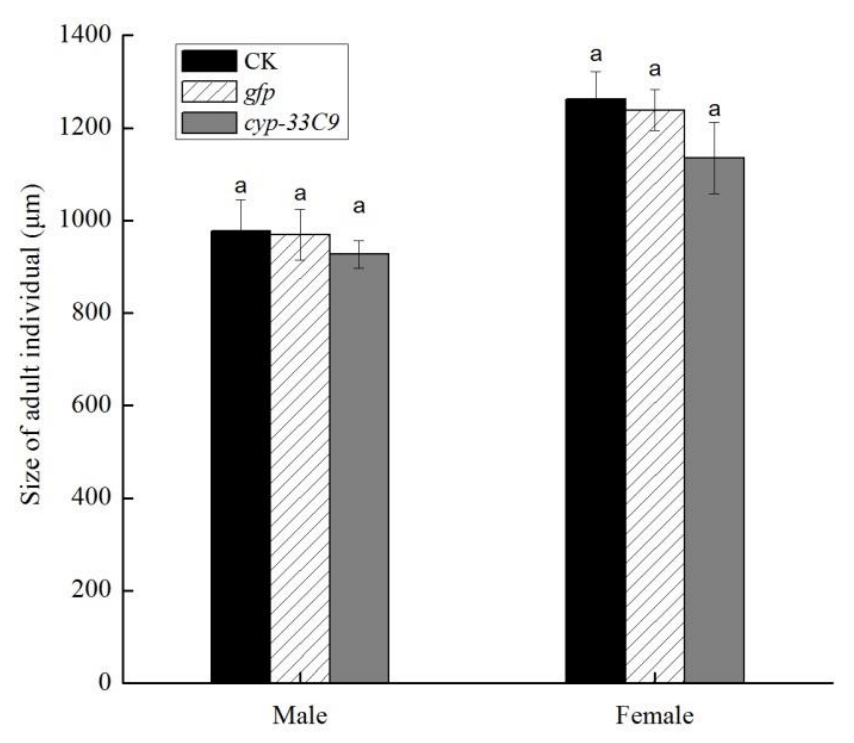

Figure 4. Effects of RNA interference on individual body length of Bursaphelenchus xylophilus. The bars indicate standard deviation, and different letters within a gender indicate significant differences $(p<0.05)$, according to Tukey's test, among the treatments.

\subsection{Determination of RNA Interference (RNAi) on Expression of cyp-33C9 in Bursaphelenchus xylophilus}

Quantitative reverse transcription PCR (qRT-PCR) was performed to test the effects of RNAi on the expression levels of the cyp-33C9 gene in nematodes soaked in target gene dsRNA solution, compared with the corresponding controls. The average expression level of the cyp-33C9 gene in B. xylophilus with $\mathrm{ddH}_{2} \mathrm{O}$ and $g f p$ dsRNA treatments were 0.92 and 0.91 , respectively (Figure 5). However, the mean expression level of the cyp-33C9 gene in nematodes soaked in target dsRNA solution was only 0.12 $(p<0.05)$. These results suggested that the cyp-33C9 gene was silenced by dsRNA interference and that non-endogenous dsRNA had no influence on the expression of the target gene.

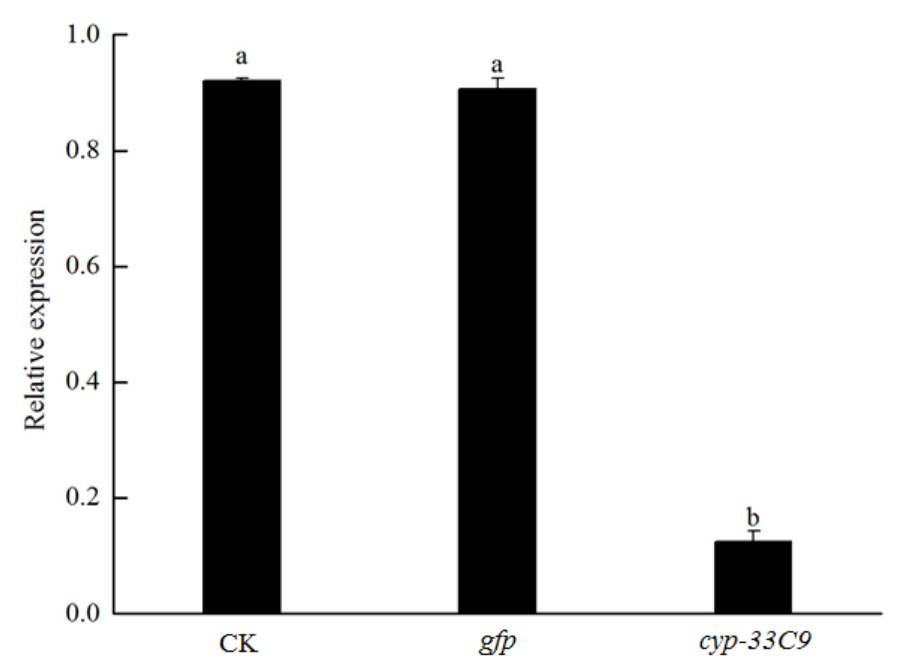

Figure 5. Quantitative reverse transcription PCR analysis of the RNA interference efficiency in Bursaphelenchus xylophilus after treatment with $\mathrm{ddH}_{2} \mathrm{O}$ or dsRNA ( $g f p$ or $\left.c y p-33 C 9\right)$. The bars indicate standard deviation, and different letters indicate significant differences $(p<0.05)$, according to Tukey's test, among treatments. 


\subsection{Effects of RNA Interference (RNAi) on Pine Wood Nematode Migration and Reproduction of Bursaphelenchus xylophilus in Pinus thunbergii}

In order to study the migration of pine wood nematodes in the host after silencing of the cyp-33C9 gene by RNAi, we counted the number of B. xylophilus in different parts of pine trees at different sampling times following inoculation of $\mathrm{J} 2 \mathrm{~s}$ which had been treated with $\mathrm{dd}_{2} \mathrm{O}$ or dsRNA. For $\mathrm{ddH}_{2} \mathrm{O}$-treated $\mathrm{J} 2 \mathrm{~s}$, there were 66 nematodes at $5 \mathrm{~cm}$ above the site of inoculation, but no nematodes existed at 10 or $15 \mathrm{~cm}$ above the site at day 5 after inoculation, whereas the number of nematodes at 5,10 and $15 \mathrm{~cm}$ below the site of inoculation were 256,57 and 9, respectively (Table 1). For cyp-33C9 dsRNA treatment, the distribution of nematodes in P. thunbergii was significantly different from that in the $\mathrm{ddH}_{2} \mathrm{O}$ treatment.

Table 1. Effects of RNA interference on migration and reproduction of Bursaphelenchus xylophilus after inoculation into Pinus thunbergii.

\begin{tabular}{|c|c|c|c|c|c|c|}
\hline Distance & Treatment & $5 d$ & $10 \mathrm{~d}$ & $15 \mathrm{~d}$ & $20 \mathrm{~d}$ & $25 \mathrm{~d}$ \\
\hline \multirow{3}{*}{$\mathrm{Up}-5 \mathrm{~cm}$} & CK & $66 \pm 8 a$ & $458 \pm 23 a$ & $4557 \pm 314 a$ & $15459 \pm 531 a$ & $16490 \pm 325 a$ \\
\hline & cyp-33С9 & $29 \pm 3 b$ & $122 \pm 15 b$ & $967 \pm 66 b$ & $7222 \pm 253 b$ & $15423 \pm 535 a$ \\
\hline & $g f p$ & $65 \pm 5 a$ & $425 \pm 28 a$ & $4224 \pm 406 a$ & $14544 \pm 854 a$ & $16117 \pm 805 a$ \\
\hline \multirow{3}{*}{$\mathrm{Up}-10 \mathrm{~cm}$} & CK & 0 & $150 \pm 12 a$ & $2350 \pm 278 a$ & $16102 \pm 438 a$ & $13445 \pm 154 a$ \\
\hline & сур-33С9 & 0 & $39 \pm 5 b$ & $371 \pm 19 c$ & $7903 \pm 346 b$ & $13591 \pm 260 a$ \\
\hline & $g f p$ & 0 & $138 \pm 21 a$ & $1789 \pm 209 b$ & $14711 \pm 1072 \mathrm{a}$ & $13731 \pm 439 a$ \\
\hline \multirow{3}{*}{$\mathrm{Up}-15 \mathrm{~cm}$} & CK & 0 & $78 \pm 7 a$ & $1482 \pm 36 a$ & $6533 \pm 322 a$ & $1328 \pm 62 a$ \\
\hline & сур-33С9 & 0 & $13 \pm 1 b$ & $187 \pm 9 \mathrm{~b}$ & $2326 \pm 172 b$ & $1299 \pm 69 a$ \\
\hline & $g f p$ & 0 & $71 \pm 7 a$ & $1487 \pm 116 a$ & $6881 \pm 224 a$ & $1343 \pm 73 a$ \\
\hline \multirow{3}{*}{ Down-5 cm } & CK & $256 \pm 30 a$ & $867 \pm 56 a$ & $6799 \pm 312 a$ & $14948 \pm 416 a$ & $13086 \pm 449 a$ \\
\hline & сур-33С9 & $84 \pm 11 b$ & $392 \pm 32 b$ & $5634 \pm 109 b$ & $15071 \pm 261 \mathrm{a}$ & $12764 \pm 422 a$ \\
\hline & $g f p$ & $246 \pm 43 a$ & $889 \pm 30 a$ & $6365 \pm 385 a b$ & $15503 \pm 428 a$ & $13272 \pm 413 a$ \\
\hline \multirow{3}{*}{ Down-10 cm } & CK & $57 \pm 6 a$ & $435 \pm 20 a$ & $7510 \pm 303 a$ & $16239 \pm 338 a b$ & $13707 \pm 129 a$ \\
\hline & сур-33С9 & $22 \pm 3 b$ & $194 \pm 11 b$ & $6512 \pm 223 b$ & $15669 \pm 210 b$ & $12871 \pm 390 b$ \\
\hline & $g f p$ & $59 \pm 3 a$ & $447 \pm 35 a$ & $7834 \pm 307 a$ & $16579 \pm 305 a$ & $13255 \pm 310 \mathrm{ab}$ \\
\hline \multirow{3}{*}{ Down-15 cm } & CK & $9 \pm 1 a$ & $152 \pm 13 a$ & $3222 \pm 169 a$ & $13247 \pm 382 \mathrm{a}$ & $10447 \pm 724 a$ \\
\hline & сур-33С9 & 0 & $42 \pm 3 b$ & $1282 \pm 47 b$ & $8246 \pm 208 b$ & $7233 \pm 533 b$ \\
\hline & $g f p$ & $7 \pm 2 a$ & $149 \pm 7 a$ & $3145 \pm 194 a$ & $12877 \pm 380 a$ & $9099 \pm 514 a$ \\
\hline
\end{tabular}

The numbers in the first column show the distance from the inoculation sites. The other numbers in the table represent the number of $B$. xylophilus from the different treatments which were recovered at each site after inoculation of $2000 \mathrm{~s}$ sstage juveniles at each inoculation site. The data represent mean values \pm standard deviation (SD) from three independent experiments. Different lowercase letters indicate significant differences $(p<0.05)$, using Tukey's test, among treatments.

These results showed that, after being inoculated into P. thunbergii, B. xylophilus nematodes migrated in two directions (up and down), with the speed of upward migration being slower than that of downward migration. In addition, the migration speed of $B$. xylophilus treated with $\mathrm{dd}_{2} \mathrm{O}$ in P. thunbergii was faster than those treated with cyp-33C9 dsRNA (Table 1). At day 10 after inoculation, the nematodes treated with $\mathrm{ddH}_{2} \mathrm{O}$ or cyp-33C9 dsRNA solution had migrated to all monitored sites of the pine trees, but the number of migrated nematodes in $P$. thunbergii following treatment with the cyp-33C9 dsRNA was significantly lower than that of nematodes treated with $\mathrm{ddH}_{2} \mathrm{O}$. This result showed that the migration speed of $B$. xylophilus treated with $\mathrm{ddH}_{2} \mathrm{O}$ in pine trees was faster than that of J2s treated with cyp-33C9 dsRNA, indicating that cyp-33C9 dsRNA treatment has a negative effect on the migration of $B$. xylophilus. The number of PWN J2s in P. thunbergii increased dramatically after $10 \mathrm{~d}$ of inoculation for all three treatments and reached the maximum at day 20 (Table 1). Interestingly, no significant difference was observed between the numbers of J2s from the three treatments at the different monitoring sites at $25 \mathrm{~d}$ after inoculation, presumably as the numbers of cyp-33C9 dsRNA-treated J2s had caught up with the control J2s (Table 1). The migration speed of 
the control J2s was not significantly different from that of the $g f p$ dsRNA-treated J2s throughout the study, indicating that non-endogenous dsRNA had no influence on the migration speed.

\subsection{Effects of RNA Interference (RNAi) on Pathogenicity of Bursaphelenchus xylophilus}

After inoculated with B. xylophilus for $25 \mathrm{~d}$, the symptoms in $P$. thunbergii were observed to determine whether treatment with RNAi affected the pathogenicity of the nematodes. Of the three nematode treatments, the 2-year-old $P$. thunbergii seedlings inoculated with B. xylophilus soaked in $\mathrm{ddH}_{2} \mathrm{O}$ appeared to wilt first, with the percentage needle wilting reaching $100 \%$ at $25 \mathrm{~d}$ after inoculation (Figure 6). At the same time, the percentage needle wilting of the P. thunbergii seedlings inoculated with B. xylophilus soaked in cyp-33C9 dsRNA solution was significantly lower at $44 \%$. In contrast, the CK P. thunbergii seedlings mock-inoculated with water (no J2s) grew well throughout the whole experiment process. These results indicated that silencing of the cyp-33C9 gene decreased the percentage wilting of P. thunbergii seedlings and reduced the pathogenicity of B. xylophilus.

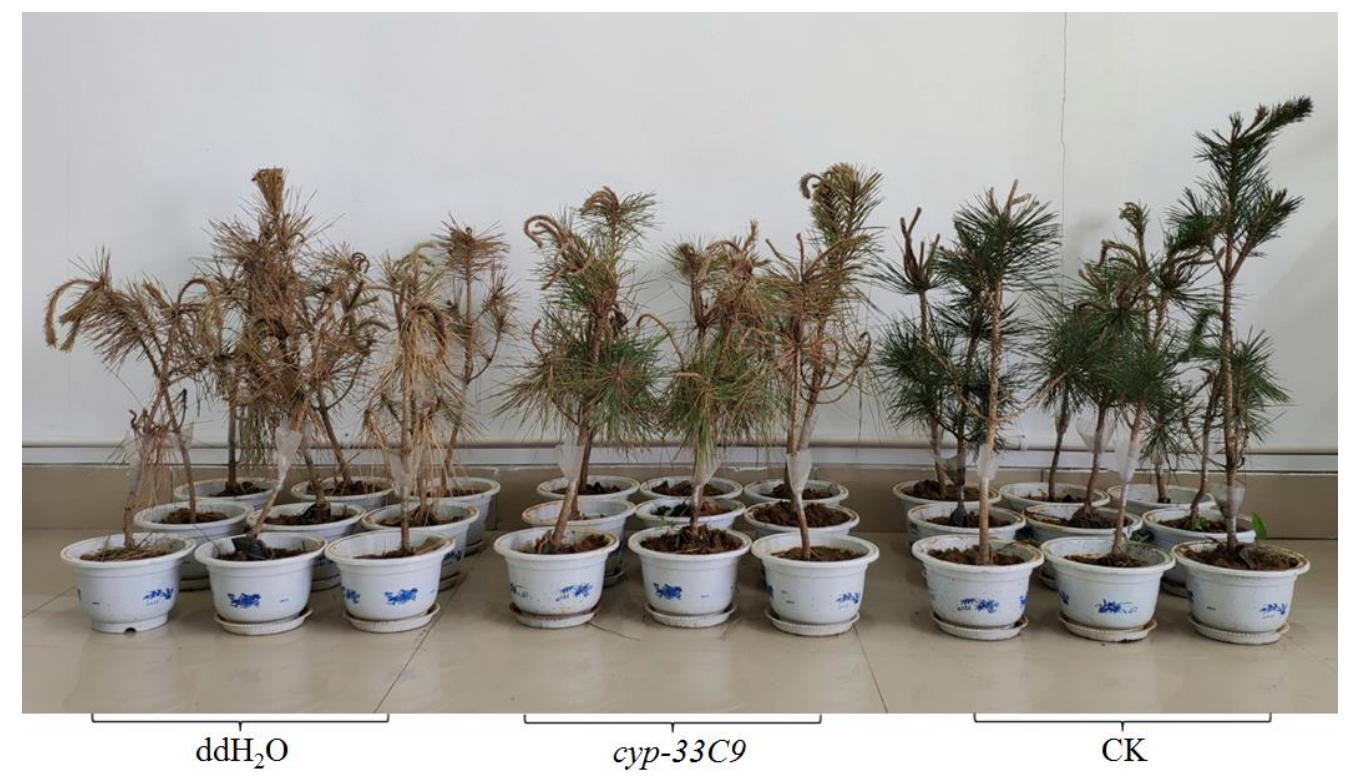

Figure 6. Wilting symptoms of $P$. thunbergii seedlings at $25 \mathrm{~d}$ after inoculation with Bursaphelenchus xylophilus soaked in $\mathrm{ddH}_{2} \mathrm{O}$ ("ddH $\mathrm{O}_{2}$ ") or cyp-33C9 dsRNA solution ("cyp-33C9"), respectively. Controls ("CK") were represented by $P$. thunbergii seedlings inoculated with $\mathrm{ddH}_{2} \mathrm{O}$ alone (no nematodes).

\section{Discussion}

The cytochrome P450s are considered to be involved in reproductive development in nematodes $[17,18]$. In the present study, we found that the cyp-33C9 gene was silenced when B. xylophilus was soaked $1 \mu \mathrm{g} \cdot \mu \mathrm{L}^{-1}$ in cyp-33C9 dsRNA solution. Xu et al. observed a similar result (with gene expression of 0.05 ) when the cyp-33C9 dsRNA solution was $800 \mathrm{ng} \cdot \mu \mathrm{L}^{-1}$ [16]. These results indicated that different cyp-33C9 dsRNA solutions did not influence RNAi. Our results showed that silencing of the cyp-33C9 gene decreased feeding and reproduction of B.xylophilus. In order to shed further light on the influences of cyp-33C9 gene on B. xylophilus, we tested the effects of RNAi on the oviposition, percentage hatch and individual body length of B. xylophilus after silencing the cyp-33C9 gene, to determine whether knockdown of the cyp-33C9 gene affected growth and development of B. xylophilus.

Eggshell formation is one of the most important factors affecting the hatching characteristics of phytoparasitic nematodes. Previous studies had shown that the eggshell of phytoparasitic nematodes is a structure with three crucial layers: vitelline layer, chitin layer and lipid-rich layer [35-37]. Benenati et al. studied the functions of cyp-31A2 and cyp-31A3 genes in C. elegans, using RNA- 
interference technology, and they discovered that both of these genes played an essential role in the development of the eggshell, especially the lipid-rich layer [17]. Their studies also showed that simultaneous depletion of $c y p-31 A 2$ and $c y p-31 A 3$ genes of $C$. elegans resulted in osmotic imbalance within the egg, impaired establishment of polarity and incorrect execution of meiosis, which eventually led to the death of $C$. elegans embryos. Interestingly, their findings mirrored those of Piano et al. who reported that the silencing of the cyp-31A2 gene of C. elegans caused embryonic lethality [38].

Cytochrome $\mathrm{P} 450$ genes also play an important role in the oviposition and egg hatch of the parasite. In this study, our results showed that the number of eggs laid per female B. xylophilus was significantly lower after the cyp-33C9 gene was silenced, and that approximately $50 \%$ of the B. xylophilus eggs produced were not capable of hatching. These results indicated that cyp-33C9 gene had a marked effect on reproduction by negatively impacting both the egg-laying capacity and the percentage egg hatch of B. xylophilus. The explanation for this may be that, at the early stage of B. xylophilus embryo development, the cyp-33C9 gene was required for formation of the lipid-rich layer of the embryo. The absence of the lipid-rich layer would have resulted in an inappropriate construction of the eggshell, which would then affect the egg-laying capacity of B. xylophilus [17]. Meanwhile, deletion of the cyp-33C9 gene of B. xylophilus appeared to result in abnormal cell division and cortical polarization of eggs, which consequently resulted in a decline in the number of hatched eggs of B. xylophilus [17]. In the present study, knockdown of the cyp-33C9 gene of B. xylophilus may be responsible directly for the abnormal development of the eggshell, which represents the permeability barrier for the embryos, ultimately leading to the decrease in oviposition number and percentage hatch of B. xylophilus eggs. In addition, cytochrome P450s have been reported to play important roles in hormone biosynthesis and metabolism [39]. The inhibited growth (as body length) and reproduction exhibited by the cyp-33C9-silenced B. xylophilus may be because the silencing of the cyp-33C9 gene inhibited the biosynthesis of hormones. The data from the present study showed that silencing of the cyp-33C9 gene, reduced the individual body length of B. xylophilus by $5-10 \%$, albeit not significantly. It has been reported that the body size of B. xylophilus is driven by somatic polyploidy and cell proliferation simultaneously [40]. Consequently, we speculate that the cyp-33C9 gene of B. xylophilus appears to have little effect on the polyploidization and proliferation of somatic cells.

After nematodes invade a plant, the host will generate a wide range of nematicidal and nematistatic substances as part of a natural resistance response to attempted infection by the nematodes [41,42]. As a consequence, the nematodes must resist or metabolize these secondary metabolites in order to invade the host successfully $[23,43]$. Cytochrome P450s play an important role in the metabolism of xenobiotic compounds in general, and this activity may enable B. xylophilus to overcome the host resistance. Our data showed that, after the knockdown of the cyp-33C9 gene of B. xylophilus, the percentage needle wilting of the $P$. thunbergii seedlings was markedly lower than that induced by the control nematodes. This result indicated that the $c y p-33 C 9$ gene may play an important role in the pathogenic process of B. xylophilus. A possible reason for this may be that silencing of the cyp-33C9 gene impaired the metabolism of xenobiotic compounds, subsequently slowing the migration of the nematodes and delaying the time course of wilting by the infected trees [44,45].

When B. xylophilus J2s had been soaked in cyp-33C9 dsRNA, the nematodes took a longer time to migrate through the host trees (Table 1). Silencing of the cyp-33C9 gene with RNAi decreased the number of nematodes in P. thunbergii seedlings compared with the control seedlings (Table 1). The results obtained by this study demonstrated that the knockdown of the cyp-33C9 gene interrupted the invasiveness, fitness, motility or reproduction of B. xylophilus during invasion of the host. These results are consistent, in part, with those reported by Cheng et al. who discovered that silencing of the Bx-eng-1 gene reduced the migration ability of B. xylophilus in Pinus bungeana [32].

In summary, this study investigated the function of the cyp-33C9 gene of B. xylophilus by dsRNA interference. The results showed that the cyp-33C9 gene could be effectively silenced by the dsRNA soaking method. We found that the silencing of the cyp-33C9 gene suppressed feeding, reproduction, oviposition, percentage hatch and pathogenicity of B. xylophilus. However, silencing of the cyp-33C9 
gene had no significant effect on the individual body length of B. xylophilus. The migration speed of B. xylophilus treated with cyp-33C9 dsRNA was reduced in the early stages when nematodes were inoculated into pine trees. These data provide fundamental information to increase our understanding of pine wilt disease (PWD) and may help to develop effective strategies to prevent and control PWD. However, further experiments are needed to investigate the molecular mechanisms by which the cyp-33C9 gene influences eggshell formation, and the correct execution of meiosis and polarization of the embryo.

\section{Materials and Methods}

\subsection{Biological Materials}

The BxJJ01 strain of B. xylophilus was isolated using Baermann funnels from infested P. thunbergii samples collected in Jiujiang City, Jiangxi Province, China. The nematodes were cultured on PDA plates covered with $B$. cinerea for five days at $25^{\circ} \mathrm{C}$. Subsequently, the nematodes were isolated from the plates with Baermann funnels and centrifuged at $1500 \times g$ for $5 \mathrm{~min}$. About 10,000 mixed-stage nematodes were decanted into a burette, which contained $25 \mathrm{~mL} \mathrm{0.3 \%} \mathrm{carboxymethyl} \mathrm{cellulose,} \mathrm{sodium}$ salt (CMC) solution. After $12 \mathrm{~h}$, the second-stage larvae were collected from the top of the burette [46].

Two-year-old $P$. thunbergii seedlings used in this study were obtained from a forest farm in Jiujiang City and were transplanted into pots $(18 \mathrm{~cm}$ in diameter, $11 \mathrm{~cm}$ in height), which were watered on alternate days. The heights of the seedlings were $40-50 \mathrm{~cm}$ and they were grown in an air-conditioned greenhouse with a relative humidity of $70 \%$ at $30^{\circ} \mathrm{C}$ during the daytime and $25{ }^{\circ} \mathrm{C}$ at night.

\subsection{RNA Isolation and cDNA Synthesis of Bursaphelenchus xylophilus}

The total RNA was extracted from nematodes using RNeasy Mini Kit (Qiagen, Valencia, CA, USA) and purified with the RNAclean Kit (Tiangen, Beijing, China), following the manufacturer's instructions. The total RNA concentration was detected at $260 \mathrm{~nm}$ using an ultraviolet spectrophotometer and its quality examined by electrophoresis on a 1\% agarose gel. RNA was reverse transcribed to cDNA using a PrimeScript 1st strand cDNA Synthesis Kit (TaKaRa, Shuzo, Japan), according to the manufacturer's instructions.

\subsection{Double-stranded RNA (dsRNA) Synthesis and in Vitro RNA Interference (RNAi)}

A fragment of cyp-33C9 gene (1200-bp) was amplified by PCR from the cDNA templates of pine wood nematodes with the following primers: forward primer $5^{\prime}$-ACTTTCCTGGTAACACTG-3' and reverse primer $5^{\prime}$-CTTTGATTCTTTGGACGA-3'. The cyp-33C9 fragments were cloned into $\mathrm{Pmd}^{\mathrm{TM}} 18$-T vector and then amplified by PCR using $\mathrm{T}_{7}$-labeled gene-specific primers as follows: forward primer 5'-TAATACGACTCACTATAGGGACTTTCCTGGTAACACTG-3' and reverse primer 5'-TAATACGACTCACTATAGGGCTTTGATTCTTTGGACGA-3'. The amplified products were used as template for synthesis of the single-strand RNA (ssRNA). The ssRNA was synthesized using a $20 \mu \mathrm{L}$ reaction volume, which contained $2 \mu \mathrm{L}$ template, $2 \mu \mathrm{L} 10 \times$ T7 reaction buffer, $2 \mu \mathrm{L}$ ATP solution, $2 \mu \mathrm{L}$ CTP solution, $2 \mu \mathrm{L}$ GTP solution, $2 \mu \mathrm{L}$ UTP solution, $2 \mu \mathrm{L}$ T7 enzyme mix, with nuclease-free water added to a final volume of $20 \mu \mathrm{L}$. The ssRNAs were mixed together and incubated at $75^{\circ} \mathrm{C}$ for $5 \mathrm{~min}$ to synthesize dsRNA. In addition, the dsRNA of green fluorescent protein gene $(g f p)$ was synthesized with the following primers: forward primer $5^{\prime}$-GTACTCGAGTGGGTTATGGTGTTCTATGCT-3' and reverse primer $5^{\prime}$-GAATCTAGAGTGGTCTCTCTTTTCGTTGG-3' [32]. Then, the dsRNA was purified to remove proteins, free nucleotides and nucleic acid degradation products. Approximately $5000 \mathrm{~J} 2$ nematodes were immersed in $500 \mu \mathrm{L}$ cyp-33C9 dsRNA solution $\left(1 \mu \mathrm{g} \cdot \mu \mathrm{L}^{-1}\right)$ and incubated in a shaking incubator at $180 \mathrm{rpm}$ for $24 \mathrm{~h}$ at $25^{\circ} \mathrm{C}$. Equal numbers of nematodes immersed in $g f p$ dsRNA solution or $\mathrm{ddH}_{2} \mathrm{O}$ without dsRNA were treated as controls. There were three replicates for each treatment. Samples from each treatment were washed with sterile water three times before use and the nematodes were collected by centrifuging at $1500 \times g$ for $3 \mathrm{~min}$. 


\subsection{Quantitative Reverse Transcription PCR (qRT-PCR)}

Quantitative reverse transcription PCR (qRT-PCR) was used to assess the effect of RNAi on cyp-33C9 mRNA levels. Total RNA was extracted from B. xylophilus following cyp-33C9 dsRNA treatment or $\mathrm{ddH}_{2} \mathrm{O}$ or $g f p$ dsRNA controls. The first-strand cDNA was synthesized and used as a template for PCR. qRT-PCR was carried out using TransStart Green qPCR SuperMix (Trans GEN Biotech, Beijing, China) in a thermal cycler (ABI Prism 7500; Applied Biosystems, Foster City, CA, USA). The primers for the cyp-33C9 gene were as follows: forward primer 5'-TCGGTTGTGGCGTGGATG-3' and reverse primer $5^{\prime}$-TGAATTATGTTCAGGCGGTT- $3^{\prime}$. The thermocycler conditions comprised one cycle of denaturation at $94{ }^{\circ} \mathrm{C}$ for $30 \mathrm{~s}$, followed by 35 cycles at $94{ }^{\circ} \mathrm{C}$ for $5 \mathrm{~s}, 60{ }^{\circ} \mathrm{C}$ for $34 \mathrm{~s}$, and $72{ }^{\circ} \mathrm{C}$ for $1 \mathrm{~min}$. The actin gene of B. xylophilus was used as the internal control. The primers for the actin gene were as follows: forward primer $5^{\prime}$-GCAACACGGAGTTCGTTGTA- $3^{\prime}$ and reverse primer $5^{\prime}$-GTATCGTCACCAACTGGGAT- ${ }^{\prime}$. The experiment had three biological replicates (with respect to independent RNA preparations) and three technical replicates.

\subsection{Effect of RNA Interference (RNAi) on Feeding and Reproduction of Bursaphelenchus xylophilus}

Two hundred nematodes (second-stage juveniles, J2s) were soaked in $\mathrm{ddH}_{2} \mathrm{O}(\mathrm{CK}), g f p$ dsRNA solution or cyp-33C9 dsRNA solution for $48 \mathrm{~h}$, respectively. The nematodes were washed three times with sterile water. Subsequently, the nematodes were transferred onto a culture of $B$. cinerea on a PDA plate and cultured at $25^{\circ} \mathrm{C}$ for $5 \mathrm{~d}$. There were three replicates for each treatment. Feeding of B. xylophilus on B. cinerea was observed and photographed. Then, the nematodes were isolated from the PDA plates using Baermann funnels and counted with an optical microscope (CX31; Olympus, Tokyo, Japan) [47].

\subsection{Effect of RNA Interference (RNAi) on Oviposition of Bursaphelenchus xylophilus}

Approximately one thousand $\mathrm{J} 2$ nematodes were soaked in cyp-33C9 dsRNA solution, $\mathrm{ddH}_{2} \mathrm{O}$ or $g f p$ dsRNA solution for $48 \mathrm{~h}$. After soaking, the nematodes were washed three times with sterile water and transferred to B. cinerea cultures on PDA plates in the dark at $25^{\circ} \mathrm{C}$ for $24 \mathrm{~h}$. Ten pairs of each of female and male adult nematodes were selected and mixed together for mating in small petri dishes (30-mm diameter) in the dark at $25^{\circ} \mathrm{C}$ for $12 \mathrm{~h}$. Subsequently, the resulting eggs laid by female nematodes were counted under an optical microscope (CX31; Olympus, Tokyo, Japan). Each treatment was replicated three times. The effects of the three different treatments on the egg-laying capacity of B. xylophilus were determined by comparing the number of eggs laid per female nematode.

\subsection{Effect of RNA Interference (RNAi) on Percentage Hatch of Bursaphelenchus xylophilus}

In order to obtain synchronous eggs, adult nematodes were transferred to petri dishes $(3 \mathrm{~cm})$ where the depth of sterile water was less than $5 \mathrm{~mm}$. After 0.5 to $1.0 \mathrm{~h}$, some nematodes had laid eggs and most of the eggs were stuck to the bottom of the petri dish. By gently removing the water and nematodes to another petri dish, the synchronous eggs were collected by washing the petri dish several times with sterile water. Subsequently, one hundred eggs were soaked in cyp-33C9 dsRNA solution, $\mathrm{ddH}_{2} \mathrm{O}$ or $g f p$ dsRNA solution at $25^{\circ} \mathrm{C}$ for $48 \mathrm{~h}$. Each treatment was replicated three times. If an egg hatched within $36 \mathrm{~h}$, the egg was considered to have hatched successfully; otherwise, an unhatched embryo was considered to be dead [48].

\subsection{Effects of RNA Interference (RNAi) on Individual Body Length of Bursaphelenchus xylophilus}

Two hundred $\mathrm{J} 2$ nematodes were soaked in cyp-33C9 dsRNA solution, $\mathrm{ddH}_{2} \mathrm{O}$ or $g f p$ dsRNA solution for $48 \mathrm{~h}$. After soaking, the nematodes were washed three times with sterile water and transferred to B. cinereal cultures on PDA plates in the dark at $25^{\circ} \mathrm{C}$ for $24 \mathrm{~h}$. The nematodes were isolated from the plates with Baermann funnels and centrifuged at $1500 \times g$ for $5 \mathrm{~min}$. Subsequently, nematodes were killed by warming up the solution to $55^{\circ} \mathrm{C}$. The nematodes were washed three times 
with sterile water and the individual body length of adult nematodes was measured under an optical microscope (CX31; Olympus, Tokyo, Japan). Forty female and forty male nematodes were measured for each treatment.

\subsection{Effects of RNA Interference (RNAi) on Migration and Reproduction of Bursaphelenchus xylophilus in Pinus thunbergii}

Approximately two thousand J2 nematodes soaked in cyp-33C9 dsRNA solution, gfp dsRNA solution or $\mathrm{ddH}_{2} \mathrm{O}$ (as control) for $48 \mathrm{~h}$ were inoculated into P. thunbergii seedlings. For each treatment, three $P$. thunbergii seedlings were cut for observation every $5 \mathrm{~d}$. After removing the branches and leaves, the trunks of $P$. thunbergii seedlings were cut into $5-\mathrm{cm}$ long sections in either direction from the site of inoculation. Subsequently, B. xylophilus in the trunks of P. thunbergii were collected by Baerman funnels and counted under an optical microscope (CX31; Olympus, Tokyo, Japan) [34].

\subsection{Effects of RNA Interference (RNAi) on Pathogenicity of Bursaphelenchus xylophilus}

The 2-year-old $P$. thunbergii seedlings were inoculated with three different preparations at about $15-20 \mathrm{~cm}$ above the soil level, and the preparations were as follows: (i) $200 \mu \mathrm{L}$ suspension of nematodes soaked in $\mathrm{ddH}_{2} \mathrm{O}$; (ii) $200 \mu \mathrm{L}$ suspension of nematodes treated with cyp-33C9 dsRNA; (iii) $200 \mu \mathrm{L}$ suspension of $\mathrm{ddH}_{2} \mathrm{O}$ without nematodes. The pine trees inoculated with B.xylophilus soaked in $\mathrm{ddH}_{2} \mathrm{O}$ or inoculated with $\mathrm{ddH}_{2} \mathrm{O}$ without nematodes were utilized as controls. Wilting symptoms of $P$. thunbergii were observed after inoculation for $25 \mathrm{~d}$. A $P$. thunbergii seedling was deemed to be dead if all its needles turned yellow. Each treatment group contained nine $P$. thunbergii seedlings. The percentage wilting was calculated using the following equation [49]:

$$
\text { The percentage wilting }=\frac{\sum \text { Number of wilted trees }}{\text { Total number of trees }} \times 100 \%
$$

\subsection{Statistical Analysis}

The results shown are the means and standard deviation (SD) of three replicates. Statistical analysis was determined using SPSS Statistics 13.0 software (IBM, Armonk, NY, USA), using one-way analysis of variance, with multiple pairwise comparisons conducted by Tukey's test.

\section{Conclusions}

In summary, this study investigated the function of the cyp-33C9 gene of B. xylophilus by dsRNA interference. The results showed that the cyp-33C9 gene could be effectively silenced by the dsRNA soaking method. We found that the silencing of the cyp-33C9 gene suppressed feeding, reproduction, oviposition, percentage hatch and pathogenicity of B. xylophilus. However, silencing of the cyp-33C9 gene had no significant effect on the individual body length of $B$. xylophilus. The migration speed of B. xylophilus treated with cyp-33C9 dsRNA was reduced in the early stage when nematodes were inoculated in pine trees. These data provide fundamental information to increase our understanding of pine wilt disease (PWD) and may help to develop effective strategies to prevent and control PWD. However, further experiments are needed to investigate the molecular mechanisms by which the cyp-33C9 gene influences eggshell formation, and the correct execution of meiosis and polarization of the embryo.

Author Contributions: X.Q. and G.Z. conceived and designed the experiments. W.W., T.Z. and H.H. performed the experiments. X.Q. and G.Z. analyzed the data. X.Q., L.Y. and G.Z. wrote the paper. J.Y. edited the paper.

Funding: This work was financially supported by the National Natural Science Foundation of China (Grant number 31660205), the Natural Science Foundation of Jiangxi, China (Grant number 20161BAB214152), the Postdoctoral Research Selected Foundation of Jiangxi (Grant number 2017KY05) and the Forestry Science and Technology Innovation Project of Jiangxi (Grant number 201711). 
Acknowledgments: We are grateful to the editor of International Science Editing (http://www.internationalscience editing.com) to improve language quality of the manuscript.

Conflicts of Interest: The authors declare no conflict of interest.

\section{References}

1. Palomares-Rius, J.E.; Tsai, I.J.; Karim, N.; Akiba, M.; Kikuchi, T. Genome-wide variation in the pine wood nematode Bursaphelenchus xylophilus and its relationship with pathogenic traits. BMC Genom. 2015, 16, 845. [CrossRef]

2. Espada, M.; Silva, A.C.; Sebastian, E.V.; Cock, P.J.; Mota, M.; Jones, J.T. Identification and characterization of parasitism genes from the pinewood nematode, Bursaphelenchus xylophilus, reveals a multilayered detoxification strategy. Mol. Plant Pathol. 2016, 17, 286-295. [CrossRef]

3. Jones, J.T.; Moens, M.; Mota, M.; Li, H.; Kikuchi, T. Bursaphelenchus xylophilus: Opportunities in comparative genomics and molecular host-parasite interactions. Mol. Plant Pathol. 2008, 9, 357-368. [CrossRef] [PubMed]

4. Mamiya, Y. Pathology of the pine wilt disease caused by Bursaphelenchus xylophilus. Annu. Rev. Phytopathol. 1983, 21, 201-220. [CrossRef] [PubMed]

5. Mamiya, Y.; Kiyohara, T. Description of Bursaphelenchus lignicolus n. sp. (Nematoda: Aphelenchoididae) from pine wood and histopathology of nematode-infested trees. Nematologica 1972, 18, 120-124. [CrossRef]

6. Cheng, H.R.; Lin, M.; Li, W.; Fang, Z. The occurrence of a pine wilting disease caused by a nematode found in Nanjing. For. Pest Dis. 1983, 4, 5.

7. Yi, C.K.; Byun, B.H.; Park, J.D.; Yang, S.I.; Chang, K.H. First finding of the pine wood nematode, Bursaphelenchus xylophilus (Steiner et Buhrer) Nickle and its insect vector in Korea. Res. Rep. For. Res. Inst. (Seoul) 1989, 38, 141-149.

8. Burgermeister, W.; Braasch, H.; Sousa, E.; Penas, A.C.; Mota, M.; Metge, K.; Bravo, M.A. First report of Bursaphelenchus xylophilus in Portugal and in Europe. Nematology 1999, 1, 727-734. [CrossRef]

9. Robertson, L.; Arcos, S.C.; Escuer, M.; Merino, R.S.; Esparrago, G.; Abelleira, A.; Navas, A. Incidence of the pinewood nematode Bursaphelenchus xylophlius Steiner \& Buhrer, 1934 (Nickle, 1970) in Spain. Nematology 2011, 13, 755-757.

10. Danièle, W.R.; René, F. Cytochromes P450: A success story. Genome Biol. 2000, 1, 1-9.

11. Menzel, R.; Bogaert, T.; Achazi, R. A systematic gene expression screen of Caenorhabditis elegans cytochrome P450 genes reveals cyp35 as strongly xenobiotic inducible. Arch. Biochem. Biol. 2001, 395, 0-168. [CrossRef]

12. Scott, J.G.; Scott, J. Insect cytochrome P450s: Thinking beyond detoxification. Recent Adv. Insect Physiol. Toxicol. Mol. Biol. 2008, 1, 17-124.

13. Li, X.; Schuler, M.A.; Berenbaum, M.R. Molecular mechanisms of metabolic resistance to synthetic and natural xenobiotics. Annu. Rev. Entomol. 2007, 52, 231-253. [CrossRef]

14. Schuler, M.A. P450s in plant-insect interactions. Biochim. Biophys. Acta. 2011, 1814, 36-45. [CrossRef]

15. Bernhardt, R. Cytochromes P450 as versatile biocatalysts. J. Biotechnol. 2006, 124, 128-145. [CrossRef]

16. Xu, X.L.; Wu, X.Q.; Ye, J.R.; Huang, L. Molecular characterization and functional analysis of three pathogenesis-related cytochrome P450 genes from Bursaphelenchus xylophilus (Tylenchida: Aphelenchoidoidea). Int. J. Mol. Sci. 2015, 16, 5216-5234. [CrossRef]

17. Benenati, G.; Penkov, S.; Muller-Reichert, T.; Entchev, E.V.; Kurzchalia, T.V. Two cytochrome P450s in Caenorhabditis elegans are essential for the organization of eggshell, correct execution of meiosis and the polarization of embryo. Mech. Dev. 2009, 126, 382-393. [CrossRef]

18. Ziniel, P.D.; Karumudi, B.; Barnard, A.H.; Fisher, E.M.; Williams, D.L. The Schistosoma mansoni cytochrome P450 (CYP3050A1) is essential for worm survival and egg development. PLoS Negl. Trop. Dis. 2015, 9, e0004279. [CrossRef]

19. Kikuchi, T.; Cotton, J.A.; Dalzell, J.J.; Hasegawa, K.; Kanzaki, N.; McVeigh, P.; Takanashi, T.; Tsai, I.J.; Assefa, S.A.; Cock, P.J.; et al. Genomic insights into the origin of parasitism in the emerging plant pathogen Bursaphelenchus xylophilus. PLoS Pathog. 2011, 7, e1002219. [CrossRef]

20. Wang, Z.; Wang, C.Y.; Fang, Z.M.; Zhang, D.L.; Liu, L.; Lee, M.R.; Li, Z.; Li, J.J.; Sung, C.K. Advances in research of pathogenic mechanism of pine wilt disease. Afr. J. Microbiol. Res. 2010, 4, 437-442.

21. Santos, C.S.; Pinheiro, M.; Silva, A.I.; Egas, C.; Vasconcelos, M.W. Searching for resistance genes to Bursaphelenchus xylophilus using high throughput screening. BMC Genom. 2012, 13, 599. [CrossRef] 
22. Cvilink, V.; Lamka, J.; Skálová, L. Xenobiotic metabolizing enzymes and metabolism of anthelmintics in helminths. Drug Metab. Rev. 2009, 41, 8-26. [CrossRef]

23. Lindblom, T.H.; Dodd, A.K. Xenobiotic detoxification in the nematode Caenorhabditis elegans. J. Exp. Zool. 2006, 305, 720-730. [CrossRef]

24. Qiu, X.W.; Wu, X.Q.; Huang, L.; Tian, M.Q.; Ye, J.R. Specifically expressed genes of the nematode Bursaphelenchus xylophilus involved with early interactions with pine trees. PLOS ONE 2013, 8, e78063. [CrossRef]

25. Chi-Ham, C.L.; Clark, K.L.; Bennett, A.B. The intellectual property landscape for gene suppression technologies in plants. Nat. Biotechnol. 2010, 28, 32-36. [CrossRef]

26. Niu, J.H.; Jian, H.; Xu, J.M.; Guo, Y.D.; Liu, Q. RNAi technology extends its reach: Engineering plant resistance against harmful eukaryotes. Afr. J. Biotechnol. 2015, 9, 7573-7582.

27. Wang, M.; Wang, D.; Zhang, X.; Wang, X.; Liu, W.; Hou, X.; Huang, X.Y.; Xie, B.Y.; Cheng, X.Y. Double-stranded RNA-mediated interference of dumpy genes in Bursaphelenchus xylophilus by feeding on filamentous fungal transformants. Int. J. Parasitol. 2016, 46, 351-360. [CrossRef]

28. Fire, A.; Xu, S.; Montgomery, M.K.; Kostas, S.A.; Driver, S.E.; Mello, C.C. Potent and specific genetic interference by double-stranded RNA in Caenorhabditis elegans. Nature 1998, 391, 806. [CrossRef]

29. Haegeman, A.; Vanholme, B.; Gheysen, G. Characterization of a putative endoxylanase in the migratory plant-parasitic nematode Radopholus similis. Mol. Plant Pathol. 2009, 10, 389-401. [CrossRef]

30. Niu, J.; Jian, H.; Xu, J.; Chen, C.L. RNAi silencing of Themeloidogyne incognita Rpn7gene reduces nematode parasitic success. Eur. J. Plant Pathol. 2012, 134, 131-144. [CrossRef]

31. Park, J.E.; Lee, K.Y.; Lee, S.J.; Oh, W.S.; Jeong, P.Y.; Woo, T.H.; Kim, C.B.; Paik, Y.K.; Koo, H.S. The efficiency of RNA interference in Bursaphelenchus xylophilus. Mol. Cells 2008, 26, 81-86.

32. Cheng, X.Y.; Dai, S.M.; Xiao, L.; Xie, B.Y. Influence of cellulase gene knockdown by dsRNA interference on the development and reproduction of the pine wood nematode, Bursaphelenchus xylophilus. Nematology 2010, 12, 225-233. [CrossRef]

33. Wang, X.R.; Cheng, X.; Li, Y.D.; Zhan, J.A. Cloning arginine kinase gene and its RNAi in Bursaphelenchus xylophilus causing pine wilt disease. Eur. J. Plant Pathol. 2012, 134, 521-532. [CrossRef]

34. Qiu, X.W.; Wu, X.Q.; Huang, L.; Ye, J.R. Influence of Bxpel1 gene silencing by dsRNA interference on the development and pathogenicity of the pine wood nematode, Bursaphelenchus xylophilus. Inter. J. Mol. Sci. 2016, 17, 125. [CrossRef]

35. Foor, W.E. Ultrastructural aspects of oocyte development and shell formation in Ascaris lumbricoides. J. Parasitol. 1967, 53, 1245-1261. [CrossRef]

36. Zhang, Y.; Foster, J.M.; Nelson, L.S.; Ma, D.; Carlow, C.K. The chitin synthase genes chs-1 and chs-2 are essential for Caenorhabditis elegans development and responsible for chitin deposition in the eggshell and pharynx, respectively. Dev. Biol. 2005, 285, 0-339. [CrossRef]

37. Johnston, W.L.; Krizus, A.; Dennis, J.W. The eggshell is required for meiotic fidelity, polar-body extrusion and polarization of the Caenorhabditis elegans embryo. BMC Biol. 2006, 4, 35. [CrossRef]

38. Piano, F.; Schetter, A.J.; Mangone, M.; Stein, L.; Kemphues, A.K. RNAi analysis of genes expressed in the ovary of Caenorhabditis elegans. Curr. Biol. 2000, 10, 1619-1622. [CrossRef]

39. Iga, M.; Kataoka, H. Recent studies on insect hormone metabolic pathways mediated by cytochrome P450 enzymes. Biol. Pharm. Bull. 2012, 35, 838-843. [CrossRef]

40. Flemming, A.J.; Shen, Z.Z.; Cunha, A.; Emmons, S.W.; Leroi, A.M. Somatic polyploidization and cellular proliferation drive body size evolution in nematodes. Proc. Natl. Acad. Sci. USA 2000, 97, 5285-5290. [CrossRef]

41. Pakharukova, M.Y.; Vavilin, V.A.; Sripa, B.; Laha, T.; Brindley, P.J.; Mordvinov, V.A. Functional analysis of the unique cytochrome P450 of the liver fluke Opisthorchis felineus. PLoS Negl. Trop. Dis. 2015, 9, e0004258. [CrossRef]

42. Fukuda, K. Physiological process of the symptom development and resistance mechanism in pine wilt disease. J. For. Res. 1997, 2, 171-181. [CrossRef]

43. Mamiya, Y. Scanning electron microscopy of pine seedling wood tissue sections inoculated with the pinewood nematode Bursaphelenchus xylophilus previously prepared for light microscopy. J. Nematol. 2012, 44, 255-259. 
44. Jones, J.T.; Haegeman, A.; Danchin, E.G.; Gaur, H.S.; Helder, J.; Jones, M.G.; Kikuchi, T.; Manzanilla-López, R.; Palomares-Rius, J.E.; Wesemael, W.M.; et al. Top 10 plant-parasitic nematodes in molecular plant pathology. Mol. Plant Pathol. 2013, 14, 946-961. [CrossRef]

45. Futai, K. Pine wood nematode, Bursaphelenchus xylophilus. Annu. Rev. Phytopathol. 2013, 51, 61-83. [CrossRef]

46. Ye, J.L.; Zhang, J.P.; Huang, L.; Tao, J.; Zhao, B.G. A method of massively isolating PWN larvae and obtaining sterile larvae. For. Pest Dis. 2011, 30, 33-35.

47. Xue, Q.; Wu, X.Q.; Zhang, W.J.; Deng, L.N.; Wu, M.M. Cathepsin L-like cysteine proteinase genes are associated with the development and pathogenicity of pine wood nematode, Bursaphelenchus xylophilus. Int. J. Mol. Sci. 2019, 20, 215. [CrossRef]

48. Bi, Z.; Gong, Y.; Huang, X.; Yu, H.; Bai, L.; Hu, J. Efficacy of four nematicides against the reproduction and development of pinewood nematode, Bursaphelenchus xylophilus. J. Nematol. 2015, 47, 126.

49. He, L.X.; Wu, X.Q.; Xue, Q.; Qiu, X.W. Effects of Endobacterium (Stenotrophomonas maltophilia) on pathogenesis-related gene expression of pine wood nematode (Bursaphelenchus xylophilus) and pine wilt disease. Int. J. Mol. Sci. 2016, 17, 778. [CrossRef]

(C) 2019 by the authors. Licensee MDPI, Basel, Switzerland. This article is an open access article distributed under the terms and conditions of the Creative Commons Attribution (CC BY) license (http://creativecommons.org/licenses/by/4.0/). 